\title{
Is Sexual-Orientation Discrimination a Form of Sex Discrimination?
}

\author{
Daniel J. Hill ${ }^{1}$ (iD \\ Published online: 5 September 2020 \\ (c) The Author(s) 2020
}

\begin{abstract}
In Bostock v Clayton County (2020) Gorsuch J holds that direct discrimination because of sexual orientation is a form of direct discrimination because of sex. I argue that the same is true under the Equality Act 2010. I consider the arguments of (Finnis, in: Finnis (ed) Intention and identity: collected essays, Oxford University Press, Oxford, 2011) and (Gardner in Oxf J Leg Stud 18(1):167-187, 1998) that "because of", "on grounds of", and similar phrases in UK discrimination legislation invoke the state of mind of the discriminator. I apply this point to Bull and Bull v Hall and Preddy [2013] arguing that (i) the UK Supreme Court was wrong to find direct discrimination on grounds of sexual orientation, while, (ii), nevertheless, under the Equality Act 2010, that case and similar cases actually involve direct discrimination because of sex, not because of sexual orientation. I conclude by considering some objections, precedents, and implications.
\end{abstract}

Keywords Finnis $\cdot$ Direct discrimination $\cdot$ Grounds $\cdot$ Sex $\cdot$ Sexual orientation $\cdot$ Bull . Equality Act 2010

\section{Introduction}

On 15 June 2020 the Supreme Court of the United States handed down judgment in three combined cases, Bostock v Clayton County (2020), Altitude Express v Zarda (2020), and Harris Funeral Homes v Equal Employment Opportunity Commission (2020). In this judgment the court held that direct discrimination because of sexual orientation or gender presentation was a form of direct discrimination because of sex. Gorsuch J, writing for the majority, stated it succinctly:

Daniel J. Hill

djhill@liverpool.ac.uk

1 Department of Philosophy, University of Liverpool, Liverpool L69 7WY, UK 
it is impossible to discriminate against a person for being homosexual or transgender without discriminating against that individual based on sex. (Bostock v Clayton County (2020))

Does anything similar hold in the UK? Is it the case that under UK law direct discrimination because of sexual orientation is a form of direct discrimination because of sex? In this essay I argue that it is the case.

The main piece of anti-discrimination legislation in force in the $\mathrm{UK}^{1}$ is the Equality Act 2010 ('the Act'). This outlaws discrimination (sections 13-25), harassment (section 26), and victimisation (section 27). Discrimination comes in two forms, direct discrimination (sections 13-18) and indirect discrimination (sections 19). The focus of this article is on direct discrimination, which is defined in section 13(1) of the Act as follows:

A person (A) discriminates against another (B) if, because of a protected characteristic, A treats B less favourably than A treats or would treat others.

The protected characteristics are listed in section 4 of the Act and explained briefly in sections 5-12 of the Act. Our focus is on the characteristics of sex (section 11) and sexual orientation (section 12).

It is to be noted that the law does not state that it is necessary either that B have the protected characteristic or that B be thought by A to have the protected characteristic. Indeed, the Explanatory Notes to the Equality Act 2010 explicitly say:

Direct discrimination occurs where the reason for a person being treated less favourably than another is a protected characteristic [...]. This definition is broad enough to cover cases where the less favourable treatment is because of the victim's association with someone who has that characteristic (for example, is disabled), or because the victim is wrongly thought to have it (for example, a particular religious belief). (Explanatory Notes to the Equality Act 2010: [59])

It will be observed that the drafter of the notes evidently thinks that "the reason for" is synonymous with "because" (the word used in the Act).

The Act supersedes, among other pieces of legislation, the Equality Act 2006 and the Equality Act (Sexual Orientation) Regulations 2007 (the Regulations), made pursuant to the Equality Act 2006. A similar definition of "direct discrimination" to that in the Act was provided in section 3(1) of the Regulations:

For the purposes of these Regulations, a person ("A") discriminates against another ("B") if, on grounds of the sexual orientation of B or any other person

\footnotetext{
1 The Act applies in whole to England and Wales, in whole apart from one section and one part to Scotland, and in only two sections and two sub-sections to Northern Ireland. See the Act, section 217.
} 
except A, A treats B less favourably than he treats or would treat others (in cases where there is no material difference in the relevant circumstances).

Another similar, though narrower still, definition was used in section 1(2) of the (now-superseded) Sex Discrimination Act 1975: ${ }^{2}$

a person discriminates against a woman if-

(a) on the ground of her sex, he treats her less favourably than he treats or would treat a man[.]

It should be observed that paragraph 61 of the Explanatory Notes to the Equality Act 2010 also comments that the difference in wording between "because of" and "on grounds of" in the various different Acts is not significant:

This section uses the words "because of" where the previous legislation contains various definitions using the words "on grounds of". This change in wording does not change the legal meaning of the definition, but rather is designed to make it more accessible to the ordinary user of the Act.

I noted above that the Sex Discrimination Act 1975 contained a narrower formulation: "on the ground of her sex" for discrimination against women, and "on the ground of his sex" for discrimination against men. (Compare also the narrow formulation of the statute at issue in Bostock v Clayton County (2020), Title VII of the Civil Rights Act 1964: "because of such individual's race, color, religion, sex, or national origin”.) In the Equality Act 2010 this is widened to include A's discriminating against B because of sex, even if it is not because of B's sex, whether male or female. It should be noted that Article 2 of Directive 2006/54/EC of the European Parliament and of the Council of 5 July 2006 on the implementation of the principle of equal opportunities and equal treatment of men and women in matters of employment and occupation (OJ 2006 L 204) employs the broader definition of "direct discrimination" in section (a) of Article 2:

direct discrimination: where one person is treated less favourably on grounds of sex than another is, has been or would be treated in a comparable situation[.] $]^{3}$

These observations are important to answer an objection from Julian Rivers (2017, personal communication, 18 July). The objection is based on section 11 of the Equality Act 2010:

\footnotetext{
${ }^{2}$ I quote the relevant subsection for the provision of goods and services, since that will loom the largest in what follows.

${ }^{3}$ I am grateful to an anonymous referee for the journal for this reference.
} 
In relation to the protected characteristic of sex-

(a) a reference to a person who has a particular protected characteristic is a reference to a man or to a woman

The objection is that this section in fact shows that the law is still working with the narrower formulation. The objection could also be based on the Explanatory Notes to the Equality Act 2010:

This section is a new provision which explains that references in the Act to people having the protected characteristic of sex are to mean being a man or a woman, and that men share this characteristic with other men, and women with other women. (Explanatory Notes to the Equality Act 2010: [54])

It seems to me that the reason why the drafters included this definition for "sex", and the effect of their including it, was to ensure that conditions such as intersex and other sexes were not counted as sexes under the Act. It should also be noted that similar definitions are provided for all the characteristics. Since the characteristic of race comes back into the discussion below, I quote this one from section 9 for comparative purposes:

In relation to the protected characteristic of race-

(a) a reference to a person who has a particular protected characteristic is a reference to a person of a particular racial group[.] (Equality Act 2010, s 9)

It is clear from paragraph 50 of the Explanatory Notes to the Equality Act 2010 that this definition of "race" is not to be taken as restricting the expansive phrase "on racial grounds" to be found in the Race Relations Act 1976. I return to this point below.

\section{Grounds}

The question arises what is meant by each of these four formulations, "on grounds of", "on the ground of", "because of", and "the reason for". In the first place, it seems on the face of it that they all relate to a mental state of the person alleged to have discriminated. As Lord Nicholls put it when considering the similar phrase "by reason that" found in section 2(1) of the Race Relations Act 1976:

Save in obvious cases, answering the crucial question will call for some consideration of the mental processes of the alleged discriminator. Treatment, favourable or unfavourable, is a consequence which follows from a decision. (Nagarajan v London Regional Transport [1999]: 511A) 
Or, to quote Lord Steyn from the same case, direct discrimination means that the discriminator's

knowledge caused or influenced the discriminator to treat the victimised person less favourably than he would treat other persons. In other words, it postulates that the discriminator's knowledge of the protected act had a subjective impact on his mind. (Nagarajan $v$ London Regional Transport [1999]: 519H-520A)

Lord Browne-Wilkinson dissented from the majority in the case, but he agreed with the majority's view that it called for consideration of a mental element:

This is a wholly subjective question directed specifically to the mental state of the alleged discriminator: why did he treat the claimant less favourably? [...]

Thus the question is essentially a subjective one: why did the alleged discriminator act as he did? My Lords, it is this very clarity of the statutory words which require the court to determine the reason why the alleged discriminator treated the claimant less favourably that makes it difficult to understand why in some of the authorities and in your Lordships' judgments the question is often posed, not subjectively, but objectively. [...]

Parliament has, in introducing legislation to outlaw discrimination on grounds of sex or race, expressly required the court to investigate the reasons which have led the alleged discriminator to take the steps which he did. This is not surprising since this was pioneering legislation designed to produce a social, as much as a legal, change. The only yardstick (in the field of direct discrimination) must be the mental state of the alleged discriminator. [...]

There is no escape from the difficulties inherent in examining the minds of the parties. (Nagarajan v London Regional Transport [1999]: 507E, 508D-E, 509E, and 509F)

There has been less judicial attempt to delineate precisely what the mental element should be, but Finnis (2011: 269) has advanced an interpretation of "grounds" that I find compelling:

Acting "on the grounds of" $\mathrm{X}$ means that X enters into the acting person's or body's deliberation in such a way as to affect that person's selection of means and/or ends.

Finnis (2011: 275) also discusses the phrase "because of", which has now replaced "on grounds of" in the definition of direct discrimination:

the definition's concern with why ("because of" what) A treated B less favourably, rather than with what factors contributed to the impact of A's conduct on $\mathrm{B}$, indicates that a decision-making body's treatment of B cannot rightly be judged direct discrimination unless at least one step in the body's actual, motivating reasoning towards decision refers to a protected characteristic. 
Finnis (2011: 274) links together the various different judicial descriptions of the mental state relevant to judgments of discrimination as follows:

Anything which (even very reluctantly) you count-and only what you countin favour of behaving the way you do appears (under the description it has in your actual practical reasoning) in the adequate account of your grounds = motives $=$ intentions $=$ ends $=$ means (and thus of your action).

So, to act on something as a ground, the thing has to motivate one to act in that way, and all such mental motivations are grounds. The above considerations do not turn just on the meaning of the word "ground". The word "on" is also relevant: if one acts on something, that means that one makes the thing one's own, one's motivating ground or reason.

John Gardner (1998: 182) goes further than Finnis in suggesting that only the "operative" premisses in one's reasoning are motivating and so relevant for the purposes of discrimination law:

"on the ground that" [...] refers to the operative rather than the auxiliary premisses of the discriminator's reasoning [...] since an auxiliary premiss has only an informational and not a motivational role in one's thinking.

One problem with this is that in real-life cases of direct discrimination it is not a hard-and-fast matter how to divide up the reasoning into "auxiliary" and "operative" premisses. Gardner (2014, personal communication, 25 July) gives this example of the thinking of a hypothetical employer:

\section{I}

(1) Every one of my employees engaging in conduct forbidden by my religious authority should be sacked by me.

(2) Everyone in a homosexual relationship is engaging in conduct forbidden by my religious authority.

Therefore,

(3) Every one of my employees in a homosexual relationship should be sacked by me.

II

(3) Every one of my employees in a homosexual relationship should be sacked by me.

(4) B is in a homosexual relationship and is one of my employees.

(5) Therefore, B should be sacked by me.

Gardner's analysis of this hypothetical example is that (1) and (3) are operative premisses, but (2) and (4) are auxiliary factual premisses. He concludes that discrimination because of sexual orientation ${ }^{4}$ is made out in this case because sexual

\footnotetext{
${ }^{4}$ Gardner does not necessarily mean this in a technical legal sense. He is speaking more generally.
} 
orientation features in an operative premiss, (3). But how can Gardner rule out a real-life employer from reasoning to the same conclusion as follows instead?

I

(1) Everyone in a homosexual relationship is engaging in conduct forbidden by my religious authority.

(2) B is in a homosexual relationship and is one of my employees.

(3) Therefore, B is one of my employees and is engaging in conduct forbidden by my religious authority.

II

(3) B is one of my employees and is engaging in conduct forbidden by my religious authority.

(4) Every one of my employees engaging in conduct forbidden by my religious authority should be sacked by me.

(5) Therefore, B should be sacked by me.

The reasoning here does not seem to be relevantly different from the point of view of discrimination law, but the switch to having (1), (2), and (3), as auxiliary premisses, and having only (4) as an operative premiss, means that on Gardner's analysis there is now no discrimination because of sexual orientation, since here sexual orientation does not feature in the only operative premiss, (4). It does not seem plausible for Gardner to say that there is a relevant difference here, so I conclude that it does not matter whether the protected characteristic occurs in an operative or an auxiliary premiss, as long as it features somewhere in the line of motivational reasoning. This also was the stance adopted by Advocate General Maduro in his opinion for the Court of Justice in Coleman v Attridge Law [2008]:

the Directive performs an exclusionary function: it excludes religious belief, age, disability and sexual orientation from the range of permissible reasons an employer may legitimately rely upon in order to treat one employee less favourably than another. In other words, after the coming into force of the Directive it is no longer permissible for these considerations to figure in the employer's reasoning when she decides to treat an employee less favourably.

[19] [...] The discriminator relies on a suspect classification in order to act in a certain way. The classification is not a mere contingency but serves as an essential premise of his reasoning. An employer's reliance on those suspect grounds is seen by the Community legal order as an evil which must be eradicated. Therefore, the Directive prohibits the use of those classifications as grounds upon which an employer's reasoning may be based. In this way, [...] the prohibition of direct discrimination [...] operates as an exclusionary mechanism (by excluding from an employer's reasoning reliance on certain grounds)[.] (Coleman v Attridge Law [2008]: 785-786 [18-19])

In any case, while initially it seems compelling that "because of", "on grounds of" etc. refer, as detailed above, to mental states, there has, nevertheless, been running against this idea a very influential judicial current dating back to the case $R v$ Birmingham City Council [1989], a case concerning whether the 
Council's provision of more places at selective schools for 11-year-old boys than for 11-year-old girls constituted discrimination on the ground of sex. Lord Goff, giving the only substantive judgment in the House of Lords, put forward a test that he took to answer the question whether the less favourable treatment was on the ground of sex. This test is now known as the "but for" test:

There is discrimination under the statute if there is less favourable treatment on the ground of sex, in other words if the relevant girl or girls would have received the same treatment as the boys but for their sex. The intention or motive of the defendant to discriminate [...] is not a necessary condition of liability; it is perfectly possible to envisage cases where the defendant had no such motive, and yet did in fact discriminate on the ground of sex. [...] [I]f the council's submission were correct it would be a good defence for an employer to show that he discriminated against women not because he intended to do so but (for example) because of customer preference, or to save money, or even to avoid controversy. ( $R v$ Birmingham City Council [1989]: 1194B-C) ${ }^{5}$

The view that Lord Goff here rejects is not the view advanced by Finnis and contended for here. The view that Lord Goff is rejecting seems to be that for there to be discrimination it is necessary that the discriminator be motivated by, or intend to bring about, the prospect of discrimination itself. This does not follow from Finnis's definition: it is true that, for discrimination to be made out, the ground of the action must be discriminatory, but it is not true that the ground must be discrimination. Further, actions can, and typically do, have more than one ground (cf. Owen and Briggs v James [1982] ICR 618: 623E (Sir David Cairns), 626A (Stephenson LJ)), and there may indeed be more than one action at issue too: the motive that leads the discriminator to adopt a discriminatory criterion or policy is only one ground; another ground - the discriminatory one in Rv Birmingham City Council [1989]— would be the motivating factor that leads the discriminator to apply the criterion or policy in a particular instance of less favourable treatment. In $R v$ Birmingham City Council [1989] the grounds that motivated, for any given 11-year-old girl, the Council to offer her less chance of a place at a selective secondary school than it offered a comparable 11-year-old boy, were simply that she was a girl and that the policy was to have fewer places open to girls. These grounds are not ruled out by what Lord Goff had to say, and, indeed, the second was found to be the ground of discrimination in the case. (The House of Lords did not consider any specific individual case of less favourable treatment, so they did not specifically mention any grounds relating exclusively to individuals.) On the other hand, the grounds that motivated the Council to adopt the discriminatory policy that it did were much more complicated: Lord Goff comments that "the history of proposals for secondary school reorganisation in Birmingham has been a history of changing policies according to the philosophy of the political party in power" (R v Birmingham City Council [1989]: 1190G).

\footnotetext{
5 The test was put forward in oral argument by Lord Lester QC and David Pannick for the Equality Commission ( $R$ v Birmingham City Council [1989]: 1184E).
} 
Lord Goff's "but for" test itself is, however, incompatible with Finnis's explanation of "ground" and with, I contend, the statute itself. This is because the "but for" test also picks out factors that are not premisses that motivate one's action, and that, thus, are not grounds on which one acts in the sense of the statute. As Finnis puts it:

the question [...] whether the complainant "would... have received the same treatment from the defendant but for his or her sex" [...] eliminates the statutorily mandated inquiry into the defendant's grounds, practical reasoning and deliberation, and intentionality, in favour of an inquiry (without statutory mandate) into the causation of the complainant's outcome. (Finnis 2011: 271-272)

Lord Nicholls also recognises the incompatibility of the "but for" test and the statutorily mandated inquiry into grounds in a 2001 case in connection with the similar phrase "by reason that":

Contrary to views sometimes stated, the third ingredient ("by reason that") does not raise a question of causation as that expression is usually understood. [...] Sometimes the court may look for the "operative" cause, or the "effective" cause. Sometimes it may apply a "but for" approach. For the reasons I sought to explain in Nagarajan v London Regional Transport [2000] 1 AC $502,510-512$, a causation exercise of this type is not required either by section I(I)(a) or section 2. The phrases "on racial grounds" and "by reason that" denote a different exercise: why did the alleged discriminator act as he did? What, consciously or unconsciously, was his reason? Unlike causation, this is a subjective test. (Chief Constable of the West Yorkshire Police v Khan [2001]: 1954 B-D [29])

\section{James v Eastleigh Borough Council (HL) [1990]}

The leading case on the concept of direct discrimination in UK discrimination law, the case of James v Eastleigh Borough Council (HL) [1990], features the "but for" test at work. The case concerned whether it was discrimination against Peter James on the ground of his $\operatorname{sex}^{6}$ to charge him for entry to the swimming baths on the ground that he was not of pensionable age, the criterion for free entry to Fleming Park Leisure Centre, Eastleigh (James v Eastleigh Borough Council (HL) [1990]: 765D). When the case was in the Court of Appeal the argument that discrimination was on the ground of his sex if the sex of the victim was "a substantial cause of the less favourable treatment" (James v Eastleigh Borough Council (CA) [1990]: 74A) was put to the court, and put as being equivalent to the "but for" test (James v Eastleigh Borough Council (CA) [1990]: 74B). The Vice-Chancellor, Sir Nicolas Browne-Wilkinson, criticized this argument:

\footnotetext{
${ }^{6}$ At this stage the narrower formulation as still used by the law (the Sex Discrimination Act 1975).
} 
What is relevant is the defendant's reason for doing an act, not the causative effect of the act done by the defendant. [...] [O]ne is looking, not to the causative link between the defendant's behaviour and the detriment to the plaintiff, but to the reason why the defendant treated the plaintiff less favourably. The relevant question is "did the defendant act on the ground of sex?" not "did the less favourable treatment result from the defendant's actions?" (James v Eastleigh Borough Council (CA) [1990]: 74C, 74D)

This reasoning seems to me sound, and quite compatible with Finnis's interpretation endorsed above. Further, the Vice-Chancellor gave an argument for this way of understanding the statute:

If there is direct discrimination in every case where there is a substantial causative link between the defendant's treatment and the detriment suffered by the plaintiff as a result of his sex I can see no room for the operation of subsection $(1)(b)$ [i.e. for indirect discrimination]. In every case in which a sexually neutral condition in fact operates differentially and detrimentally to one sex as opposed to the other, the imposition of such a condition would be a substantial cause of detriment to the plaintiff by reason of his or her sex, i.e. it would $[\ldots]$ therefore constitute direct discrimination [...].

This plainly was not the intention of Parliament which was drawing a clear distinction between, on the one hand, those cases where the defendant expressly or covertly acts by reference to the sex of the plaintiff and, on the other, those cases where the defendant acted on grounds not expressly or covertly related to sex but his actions have caused a disparate impact as between the sexes. (James v Eastleigh Borough Council (CA) [1990]: 75DF)

This argument seems very plausible to me: the "but for" test would level the distinction between direct and indirect discrimination. The only way in which the significance of the distinction may plausibly be understood is if direct discrimination is decided by reference to the subjective factors of the alleged discriminator's motivation, and indirect discrimination is decided by reference to objective, causative factors. The argument did not, however, compel Lord Bridge, who, in giving the leading judgment when James came to the House of Lords, adopted Lord Goff's "but for" test:

Lord Goff's test, it will be observed, is not subjective, but objective. Adopting it here the question becomes: "Would the plaintiff, a man of 61, have received the same treatment as his wife but for his sex?" An affirmative answer is inescapable. (James v Eastleigh Borough Council (HL) [1990]: 765D)

In rejecting the appropriateness of the "but for" test I am not saying that James was not a case of direct discrimination. If Mr James's sex (as opposed to the mere fact of his not being of pensionable age) really was a factor in the reasoning that led 
to his being turned away then he was directly discriminated against—but this is a matter on which evidence should have been taken. ${ }^{7}$

It might be thought that, whether or not correct, the precedent here is decisive, but, in addition to the words of Lord Nicholls in Chief Constable of the West Yorkshire Police v Khan [2001], there are the words of Lord Phillips from his judgment in a case from 2009:

This "but for" test was another way of identifying the factual criterion that was applied by the council as the basis for their discrimination, but it is not one that I find helpful. It is better simply to ask what were the facts that the discriminator considered to be determinative when making the relevant decision. $(R(E)$ v Governing Body of JFS [2009]: 747D-E [16])

This indicates that courts are not bound to implement the "but for" test. To sum up, I contend that (i) the "but for" test does not conform to either the current statute or its predecessors relating to discrimination, (ii) the test should no longer be applied, and (iii) the courts should focus on attempting to determine whether the relevant protected characteristic featured as a ground of the less favourable treatment in question, i.e. whether the relevant protected characteristic motivated the actual imposition of the less favourable treatment.

\section{The Ground of Sexual Orientation Versus The Ground Of Sex}

I shall now apply the foregoing considerations to cases of alleged direct discrimination because of, or on grounds of, sexual orientation, focussing on the case of Bull and Bull v Hall and Preddy [2013]. The reason for this is that I shall be arguing that the judgment in this case was incorrect: it was not a case of direct discrimination on grounds of sexual orientation. I shall, however, be maintaining that the ingredients are made out, under the later Equality Act 2010, for direct discrimination because of sex. These results will generalize to similar cases.

The facts in Bull and Bull v Hall and Preddy [2013] are that Steven Preddy and Martyn Hall, who were gay men in a civil partnership with each other, were turned away on 5 September 2008 from the double room that they had booked in the Chymorvah Hotel, which was owned and run by Peter and Hazelmary Bull with assistance from Bernard Quinn. The criterion given by the Bulls for their renting out of double rooms was "we prefer to let double accommodation to heterosexual married couples only" (Hall and Preddy v Bull and Bull [2011]: [11]). It is important to note that "heterosexual" means here "of the opposite sex", not "of a heterosexual orientation" (Bernard Quinn 2014, personal communication, 24 July). Hall and Preddy alleged direct discrimination on grounds of sexual orientation, which was

\footnotetext{
7 In the judgment of the Court of Appeal it is recorded that in the court of first instance (Southampton County Court on 28 October 1987 before Judge Tucker) "it was common ground that the council's policy was discriminatory within the meaning of section 1 of the Act", so this point did not require any evidence to be adduced or accepted.
} 
the finding of the Bristol County Court (Hall and Preddy v Bull and Bull [2011]: [11]), the Court of Appeal (Bull and Bull v Hall and Preddy [2012]), and the UK Supreme Court (Bull and Bull v Hall and Preddy [2013]).

The leading judgment from the Supreme Court was by Baroness Hale. She argues that the Bulls directly discriminated on grounds of sexual orientation. The Bulls contended that they discriminated on grounds of marital status (Bull and Bull v Hall and Preddy [2013]: 3747G [17]). (Although the case was heard under the Sexual Orientation Regulations 2007, it is worth noting that the characteristic of marriage or civil partnership was not then covered by discrimination legislation respecting services and public functions, and even now is not covered by the relevant part, Part 3, of the Equality Act 2010. Same-sex marriage was not introduced in England and Wales until the Marriage (Same-sex Couples) Act 2013.) The crucial paragraph of Lady Hale's judgment is, in my opinion, [29]:

I would [...] regard the criterion of marriage or civil partnership as indissociable from the sexual orientation of those who qualify to enter it. More importantly, there is an exact correspondence between the advantage conferred and the disadvantage imposed in allowing a double bed to the one and denying it to the other. (Bull and Bull v Hall and Preddy [2013]: 3750F [29])

Contrary to Lady Hale, the criterion is clearly not indissociable from sexual orientation, since (a) those of a heterosexual orientation do not have to marry, and, as she herself points out, (b) those of a homosexual orientation have always been free to get married (Bull and Bull v Hall and Preddy [2013]: 3748F [20]). Lady Hale responds to this point "They are not free to marry a person who shares their own orientation" (Bull and Bull v Hall and Preddy [2013]: 3748F [20]). But this is, again, false, as her own example shows: Vita Sackville-West was of a homosexual orientation, and she married another person of a homosexual orientation, Harold Nicholson (Bull and Bull v Hall and Preddy [2013]: 3748F [20]). ${ }^{8}$ What is true is that one was not at the time legally free to marry someone of the same sex: this is only indirectly discriminatory under the Sexual-Orientation Regulations 2007, though I shall argue that it would have constituted direct discrimination because of sex under the Equality Act 2010.

Lady Hale secondly asserts that there is an "exact correspondence between the advantage conferred and the disadvantage imposed in allowing a double bed to

\footnotetext{
${ }^{8} \mathrm{NB}$ that s 12(1) of the Equality Act 2010 states “Sexual orientation means a person's sexual orientation towards-

(a) persons of the same sex,

(b) persons of the opposite sex, or

(c) persons of either sex."

So, "being sexually oriented towards men" and "being sexually oriented towards women" are not examples of sexual orientation within the meaning of the Act. The Explanatory Notes make this clear at paragraph 57:

- A man and a woman who are both attracted only to people of the opposite sex from them share a sexual orientation.

- A man who is attracted only to other men is a gay man. A woman who is attracted only to other women is a lesbian. So a gay man and a lesbian share a sexual orientation.
} 
the one and denying it to the other" (Bull and Bull v Hall and Preddy [2013]: 3748A [18]). This sentence should not be read literally, as it would then be obviously false: the category of those suffering a disadvantage did not coincide exactly with those with the protected characteristic, since (i) unmarried opposite-sex couples of heterosexual orientation were also barred from double rooms and, unnoted by Lady Hale (but noted by HHJ Rutherford in his judgment at the County Court (Hall and Preddy v Bull and Bull [2011]: [33])), (ii) two people of the same sex and of heterosexual orientation were also barred from sharing a double room, and (iii) a man of homosexual orientation and a woman of homosexual orientation, if married to each other, would be welcomed by the Bulls to share a double room (Bernard Quinn 2014, personal communication, 24 July). Rather, this sentence of Lady Hale's is to be understood as restricted to the comparison between an opposite-sex married couple and a couple in a civil partnership (by definition then a same-sex couple); this is how Lord Neuberger takes the sentence too (Bull and Bull v Hall and Preddy [2013]: 3761G [82]). If one restricts oneself to this comparison then there is indeed an exact correspondence: the opposite-sex married couple will be given the double room, and the couple in a civil partnership will be denied it. This is admitted by the Bulls. But how are we supposed to get from here to a finding of direct discrimination on grounds of sexual orientation?

Lady Hale first cites a precedent from the Court of Justice of the European Communities (now the European Union) (Maruko $v$ Versorgungsanstalt der Deutschen Bühnen [2008]). In this case the Grand Chamber of the Court of Justice had considered whether, to quote Lady Hale's summary, treating "a surviving life partner less favourably than a surviving spouse, by denying him a survivor's pension, was direct discrimination within the meaning of the equal treatment directive" (Bull and Bull v Hall and Preddy [2013]: 3750C [28]). The court said:

According to Art.2(2)(a) of Directive 2000/78, direct discrimination occurs where one person is treated less favourably than another person who is in a comparable situation, on any of the grounds referred to in Art.1 of the Directive. (Maruko v Versorgungsanstalt der Deutschen Bühnen [2008]: 954 [66])

This is standard, but the court concludes:

If the referring court decides that surviving spouses and surviving life partners are in a comparable situation so far as concerns that survivor's benefit, legislation such as that at issue in the main proceedings must, as a consequence, be considered to constitute direct discrimination on grounds of sexual orientation, within the meaning of Arts 1 and 2(2)(a) of Directive 2000/78. (Maruko v Versorgungsanstalt der Deutschen Bühnen [2008]: 955 [72])

It is apparent that there is no mention of the discriminator's grounds in this paragraph. In consequence, this part of the court's judgment must be considered mistaken: a necessary ingredient of direct discrimination is that one discriminate on the ground of, or because of, a protected characteristic, and this has not 
been established in this case. (I am not saying that the court simply forgot about grounds; I think that the court conceived, wrongly, that if one treated someone less favourably than a relevant comparator without the protected characteristic it must be on grounds of that characteristic. This is how Lord Neuberger understands it (Bull and Bull v Hall and Preddy [2013]: 3761E [81]).) Maruko v Versorgungsanstalt der Deutschen Bühnen [2008] does not, however, establish a binding precedent on domestic law, as is noted by Lord Neuberger (Bull and Bull v Hall and Preddy [2013]: 3761G [81]).

Now, Lady Hale does add an additional reason towards the end of her consideration of direct discrimination:

When it came to denying a double bed to Mr Preddy and Mr Hall, which they would have given to a heterosexual married couple, $\mathrm{Mr}$ and Mrs Bull were not only applying the criterion that they were unmarried. They were applying a criterion that their legal relationship was not that of one man and one woman, in other words a criterion indistinguishable from sexual orientation. (Bull and Bull v Hall and Preddy [2013]: 3750H [30])

It should be clear by now that the criterion certainly was distinguishable from sexual orientation: as was discussed above, the Bulls would have barred two backpackers of the same sex and of heterosexual orientation from sharing a double room (Hall and Preddy v Bull and Bull [2011]: [33]), and they would have allowed Vita Sackville-West and Harold Nicholson to share a double room. Nevertheless, Lady Hale is correct: the Bulls' criterion was not merely "only married couples can have a double room", it was "only heterosexual [i.e. opposite-sex] married couples can have a double room". Despite this, I still think that this is not a case of direct discrimination on grounds of sexual orientation: there is no mention of that in the criterion at all, nor, as we have seen, is it hidden in the word "married". (One can imagine that a legislature might have allowed only those of heterosexual orientation to marry, by asking the parties what their sexual orientation was before pronouncing them married, yet, as far as I know, no legislature has done anything like this.)

Although the "but for" test does not explicitly feature in the judgment of Lady Hale, it does feature in the concurring judgment of Lord Toulson JSC:

[In] this case the question [from James $v$ Eastleigh Borough Council [1990]] becomes: would the claimants have received the same treatment as married heterosexuals but for their sexual orientation? (Bull and Bull v Hall and Preddy [2013]: 3759G [71])

Lord Toulson takes the answer to this question to be "yes". But this is wrong: two men not of homosexual orientation like the backpackers discussed above would still have been denied a double room. It seems to me that a better way for Lord Toulson to have applied the "but for" test would have been: "would the claimants have received the same treatment as an opposite-sex couple but for their being of the same sex?". It seems to me that the answer to this question is clearly "yes", since the relevant comparator to a couple in a civil partnership is 
established in section 3(4) of the Sexual Orientation Regulations 2007 to be a married couple. But all this presupposes that the "but for" test is a good test, and I have already argued at length that it is not to be relied upon.

So, if the "but for" test is not to be relied upon, how is one to decide cases like this? While it seems clear from the foregoing that sexual orientation was not a ground of the Bulls' less favourable treatment of Hall and Preddy, the curious thing is that it looks as though the very words of the Bulls' actual criterion show that the Bulls, in applying it, directly discriminated against Hall and Preddy because of, or on grounds of, sex, not on grounds of sexual orientation. ${ }^{9}$ The criterion does not say just "married couples only" but "heterosexual married couples only"; the addition of the word "heterosexual" to "married couples" to produce the actual criterion the Bulls used seems to me significant. As stated above, the Bulls did not use "heterosexual married couples" to mean "people of heterosexual orientation married to each other". 10 They used it to mean simply "different-sex married couples". Now the discrimination is plain to see: it is direct discrimination because of sex, to use the phrase of the Equality Act 2010. The Bulls are saying that they will refuse double rooms to any couples of the same sex (as well as some, unmarried, couples of different sexes). In other words, while they will let Preddy have a double room to himself, they will not allow another man, whatever his relationship to Preddy, to stay in the room with him, and that because of his being the same sex as Preddy. And that is direct discrimination because of sex, just as refusing to allow someone else of the same race to stay in the room with him for that reason would be direct discrimination because of race. Or, to give an example of more historical plausibility, just as refusing to allow someone else of a different race to stay in the room with him for that reason would be direct discrimination because of race. It would be no answer to say that this criterion hit all races equally hard, that whites were equally prevented from sharing with blacks as the corollary of blacks' being prevented from sharing with whites. ${ }^{11}$ And it follows by parity of reasoning that it is no answer to a charge of discrimination because of sex to say that, since men are prevented from sharing with other men and women are prevented from sharing with other women, the criterion that only different-sex couples may share a double room hits both sexes equally hard.

\footnotetext{
${ }_{9}$ Although I am, as far as I know, the first person to apply this argument directly to Bull and Bull v Hall and Preddy [2013], the argument has been deployed more generally by many others, e.g. Pannick (1983), reprinted as Chapter 8 in Pannick (1985), Koppelman (1996), Koppelman (1994, 2001, 2002), and Wintemute (1997a, b, 2003).

${ }^{10}$ Trispiotis (2014: 43) states that "the sexual orientation of the couple figured not in the auxiliary premise (as the appellants claim it to be when they insist that they only wanted to accommodate married couples) but in the operative". But in fact the sexual orientation figures in no premiss of the Bulls' reasoning. ${ }^{11}$ It was, however, enshrined in some US court judgments, eg Pace v Alabama (1883: 585). Harlan J also mentions the argument as having been advanced by counsel in his dissenting judgment Plessy v Ferguson (1896: 557). The argument was also advanced by the State of Virginia; cf. the judgment of Warren CJ, Loving v Virginia (1967: 8). The "hits both sexes equally hard" version also features in the judgment in Grant v South-West Trains Ltd [1998].
} 


\section{Confirming Precedents}

The reader may wonder whether there be any precedent in the UK for finding direct discrimination because of sex along these lines. In Grieg $v$ Community Industry [1979] Ann Grieg was refused team employment with Community Industry on the grounds that "there would only have been one girl member of the team [which would have] created an imbalance in the composition of the team which was wholly unacceptable" (Grieg v Community Industry [1979]: 358E). Counsel for Community Industry argued that there was no direct discrimination on grounds of sex because Community Industry would have turned down one man applying for a vacancy in an otherwise all-female team (Grieg v Community Industry [1979]: 360F-H). This argument was rejected by the Employment Appeal Tribunal (Grieg v Community Industry [1979]: 361 A-D), which found that Community Industry had directly discriminated against Grieg, stating that "the applicant was refused because she was a girl and had a man applied he would, had he been otherwise suitable, have been taken into the team" (Grieg v Community Industry [1979]: 361G). What is particularly interesting about this is that the Employment Appeal Tribunal did not reject Grieg's argument on the basis that the discrimination was on the ground of "sexual imbalance" rather than of "sex".

The parallel with Bull is instructive: the Bulls think that there being two people of the same sex creates "an imbalance" in the composition of the occupancy of a double room that is wholly unacceptable, and, had a woman applied for the position of room-sharer with Preddy, she would, unlike Hall, have been allowed in, had she been "otherwise suitable" (i.e. married to Preddy).

A somewhat similar case is Bain v Bowles [1991]. Here Bowles refused to allow Bain, a man, to place an advert in The Lady for a "working housekeeper cook" (Bain $v$ Bowles [1991]: 357 [3]). Bowles attempted to justify the refusal by reference to this policy:

We only include advertisements for female employees outside the United Kingdom when the employer is a woman and resident in the household concerned. (Bain v Bowles [1991]: 357 [3]).

Here Bowles might argue that The Lady did not discriminate against Bain because of sex, but only because of oppositeness of sex of employer and employee, i.e. because of the fact that Bain's sex happened to be opposite to that of the employee sought. ${ }^{12}$ The Court of Appeal, however, found direct discrimination on the ground of Bain's sex.

It is racial cases in which the defectiveness of the putative defence that the Bulls discriminated not because of sex, but because of sameness of sex, is most obvious. The US case Loving $v$ Virginia is a clear example of this: the US Supreme Court held that Virginia's ban on mixed-race marriages rested "solely upon distinctions drawn according to race" and on "racial classifications" (1967: 11). By parity of

12 In fact, Bain did not say in his advert that the cook would have to be female. 
reasoning, a ban on same-sex couples or mixed-sex couples must rest on "distinctions drawn according to sex". Although there does not seem to have been a precisely similar English case, Lord Simon did remark obiter in the House of Lords that "discriminating against a white woman on the ground that she had married a coloured man" would fall within the purview of the Race Relations Act 1968 (Applin v Race Relations Board [1974]: 290A), and Lord Denning said obiter in the Court of Appeal in the same case that a hypothetical case of a publican's barring white women that came in with black men would be direct discrimination "on the ground of colour" (Race Relations Board v Applin [1973]: 828C). The parallel is clear: if a ban on mixed-race or same-race couples is direct discrimination because of race, then a ban on mixed-sex or same-sex couples is direct discrimination because of sex.

These precedents reinforce my conclusion that, while the UK Supreme Court erred in finding Bull a case of direct discrimination on grounds of sexual orientation, had the case been heard under the Equality Act 2010, the correct decision would have been that the Bulls had directly discriminated because of sex.

\section{Objections}

It might be objected that this line of argument, while it may have been established for the United States by Bostock v Clayton County (2020), has already been decisively rejected in the UK courts, most famously by the House of Lords in Advocate General v MacDonald [2003]. (Lord Prosser's dissenting judgment at the earlier stage in the Inner House had embraced the argument I have put forward: Advocate General v MacDonald [2001]: 9-15 [21]-[40].) I quote from the leading judgment in the House of Lords, given by Lord Nicholls:

10 I should also mention an argument based on the Race Relations Act 1976 (cap 74). The appellants sought to rely on the analogy of the restaurateur who refuses to serve mixed race couples. He will not admit a black man accompanied by a white woman, or a white man accompanied by a black woman. This, it was said, would be racial discrimination. It would be racial discrimination even though the restaurateur's policy applied equally to men of all races.

11 I agree. That would be racial discrimination. But the analogy sought to be drawn with the present cases is unsound. A restaurateur who refuses to serve a black man because he is accompanied by a white woman would thereby be discriminating on "racial grounds". That phrase is amply wide enough to include such a case. This treatment would not cease to be discrimination on racial grounds because the restaurateur would equally discriminate on racial grounds in the converse situation of a white man and a black woman.

12 This is to be contrasted with the present cases. An employer who dismisses a male employee because of his sexual orientation is not discriminating against him on the ground of his sex. (Advocate General v MacDonald [2003]: 40, [10]-[12]) 
The first thing to note here is that since the Equality Act 2010 broadened the grounds of direct discrimination in this respect from "on the ground of her [or his] sex", as found in sections 1(1)(a) and 1(2)(a) of the Sex Discrimination Act 1975, to the Equality Act 2010's phrase "because of sex", Lord Nicholls's contrast drawn above falls away.

At this point a supporter of the line taken by Lord Nicholls in 2003 might recur to an objection I mentioned near the start based on the Explanatory Notes to the Equality Act 2010, which state, in commenting on the Act's definition of "because of sex":

This section is a new provision which explains that references in the Act to people having the protected characteristic of sex are to mean being a man or a woman, and that men share this characteristic with other men, and women with other women.

The objection goes that neither Hall nor Preddy was discriminated against because he was a man (or, obviously, because he was mistakenly thought to be a woman), so there is no direct discrimination because of sex (compare the dissenting opinion of Circuit Judge Sykes in Hively v Ivy Tech Community College (2017): 52, and the dissenting opinion of Alito J in Bostock $v$ Clayton County (2020)). A related objection from Julian Rivers (2017, personal communication, 18 July) is that the Bulls discriminated not because of sex, but because of sameness of sex (two women in a civil partnership would also have been refused a double room). Rivers adds that while Hall and Preddy each have a sex, the couple does not have a sex, so one cannot say that it is the couple that is discriminated against. Finally, it is objected that if the meaning of "because of sex" were as broad as I am suggesting then there would be no need for the drafter to have included section 14 of the Equality Act 2010 to deal with "combined", also known as "intersectional", discrimination:

A person (A) discriminates against another (B) if, because of a combination of two relevant protected characteristics, A treats B less favourably than A treats or would treat a person who does not share either of those characteristics. ${ }^{13}$

It should first be noted that, on the face of it, these objections, if they were successful, would tell against forbidding a mixed-race couple a double room. Suppose that $\mathrm{A}$ is a black man and $\mathrm{B}$ a white woman, and that $\mathrm{C}$ refuses them a double room on the grounds that $\mathrm{A}$ and $\mathrm{B}$ are not of the same race. $\mathrm{C}$ could, by the objection before us at the moment, argue that $\mathrm{A}$ is not being discriminated against because of his race (as he would have been admitted had B been black too), and that B is not being discriminated against because of her race (as she would have been admitted had A been white too). Further, $\mathrm{C}$ could insist that there was no discrimination because of race, but just because of sameness of race, and that, in any case, neither A nor B, but only

\footnotetext{
13 It should be noted that, as of the time of writing, section 14 of the Equality Act 2010 has still not been brought into force, and that there is a considerable current of academic writing that holds that it is redundant (e. g. Hand 2011).
} 
the couple of $A$ and $B$, has been discriminated against. It should be remembered that the Equality Act 2010 treats sex, race, and the other protected characteristics alike in this respect (direct discrimination).

It seems to me, in any case, that there is a strong argument against the contention that neither Hall nor Preddy was discriminated against because he was a man: when Preddy booked a double room by telephone on 4 September 2008 the Bulls thought that he was booking it for himself and a woman, whom they assumed to be his wife (Hall and Preddy v Bull and Bull [2011]: [11]-[12]). Now imagine Preddy's coming into the hotel the next day (Hall and Preddy v Bull and Bull [2011]: [13]): he is initially welcomed in, but when the Bulls see the sex of the person entering the hotel with him, everything changes. It is clear that the Bulls will let Preddy stay on his own in the double room, but will not let Hall in with him, because he is a man. Had Hall been a woman, and married to Preddy, they would have let him in, as they would have done had Preddy been a woman married to Hall. Hence it is clear that Hall is refused entry because he is not a woman married to Preddy. And this is discrimination because of sex (as well as marital status), just as refusing him entrance because he was not a white married to Preddy would have been discrimination because of race (as well as marital status). And there is discrimination against Preddy too: in being denied Hall's company in the double room he is treated less favourably because he is a man than he would have been had he been a woman married to Hall.

It may still be objected that refusing Hall because he does not meet the compound condition woman-not-married-to-Preddy is not the same as refusing Hall because he meets the simple condition being a man. (Compare Alito J: "Title VII prohibits discrimination because of sex itself, not everything that is related to, based on, or defined with reference to, 'sex"': Bostock v Clayton County (2020): dissent, fn 5.) But the legal equivalence between marriage and a civil partnership means that the only part of the compound condition that Hall fails to meet is being a woman (see section 3(4) of The Equality Act (Sexual Orientation) Regulations 2007), and the Bulls not only knew this, but based their rejection of Hall on their knowledge that he was a man (they did not, of course, inquire whether he was married to Preddy). So, while out of the set of potential room-sharers for Preddy the Bulls rejected all men, even ones that might be just sharing a bed to save money rather than out of any relationship (Hall and Preddy v Bull and Bull [2011]: [33]), out of the set of potential room-sharers either married to or in a civil partnership with Preddy, the Bulls would have rejected all and only men. ${ }^{14}$ It might be further objected that the fact that the Bulls would have rejected all and only the men from this set does not show that they rejected them because they were men. But this is the description of what happened at the Bulls' hotel on that day:

[Hall and Preddy] drove from Bristol to Cornwall and presented themselves at the hotel to be met by Mr Quinn who informed them of the hotel's policy with

\footnotetext{
14 Recall that at this point the law of England and Wales provided only for opposite-sex marriages, and only for same-sex civil partnerships.
} 
regard to double rooms. [Hall and Preddy] explained that they were in a civil partnership but were told by Mr Quinn that only mixed sex married couples could have double rooms.

(Hall and Preddy v Bull and Bull [2011]: 13)

Why did Quinn inform them of this policy? The answer is obvious: he could see that they were both men. He seems already to have known that Preddy was a man from the telephone booking (Hall and Preddy v Bull and Bull [2011]: 12), but he did not know that the person wanting to share the double room with Preddy was also a man. Quinn's reasoning, on behalf of the Bulls, evidently went like this:

(1) Preddy is a man.

(2) Hall is a man.

(3) Two men do not make an opposite-sex married couple.

(4) Therefore, Hall and Preddy do not make an opposite-sex married couple.

(5) Those that do not make an opposite-sex married couple should not be allowed to share a double room.

(6) Therefore, Hall and Preddy should not be allowed to share a double room.

It is clear that Hall's sex, and Preddy's sex, played an essential role in this chain of reasoning. Had Quinn not realized that Hall was a man, or that Preddy was a man, he would not have come to the conclusion that he did. Therefore, the decision to refuse the double-room was taken in part because Hall was a man, and in part because Preddy was a man, as well as in part because of the belief that it was wrong to allow a same-sex couple to share a double room. Therefore, the decision was in part because of sex, contrary to the provisions of the Equality Act 2010. ${ }^{15}$

The fact that the decision was only in part because of sex does not show that it was not direct discrimination because of sex. If the criterion had been "no black couples and no unmarried couples" it would have been clearly direct discrimination because of race; if it had been "no couples over 60 and no unmarried couples" it would have been clearly direct discrimination because of age. So, by parity of reasoning, the Bulls' criterion "no same-sex couples and no unmarried opposite-sex couples" clearly constitutes direct discrimination because of sex. The addition of a new criterion does not in any way nullify an existing criterion. Compare also the pronouncement of the Court of Appeal (Owen and Briggs v James [1982]: 623E) that discriminatory conduct does not have to be animated solely by the discriminatory ground.

Finally, it should be noted that even if intersectional discrimination is not covered by the Equality Act 2010 that does not tell against the argument that I have been deploying. Intersectional discrimination occurs when someone is discriminated against because they combine two protected characteristics. For example, it may be

\footnotetext{
15 In the case of Black and Morgan $v$ Wilkinson [2013] the reasoning is even clearer: Wilkinson "made it clear that she would not accommodate them because she did not like the idea of two men sharing a bed" (2495C [6]). See further discussion below.
} 
that A discriminates against black women but not against black men, and not against white women. It is disputed (cf. Hand 2011) whether in this case there would be no discrimination because of sex and no discrimination because of race, but in the case of the Bulls all men are discriminated against when it comes to the position of room-sharer with Preddy. It is not the intersection of the characteristic of being a man with another characteristic that rules out Hall from sharing a room with Preddy. Rather, being a man suffices all by itself to rule Hall out for that position.

\section{The European Court of Justice}

The argument deployed here that most cases commonly thought to be direct discrimination because of sexual orientation are actually cases of direct discrimination because of sex was discussed in the European case Grant $v$ South-West Trains [1998]. In this case Lisa Grant complained that South-West Trains had discriminated based on sex contrary to Article 119 of the Treaty establishing the European Community in offering travel concessions to her predecessor's, opposite-sex, partner but refusing them to her own, same-sex, partner (Grant v South-West Trains [1998]: 1007 [7]-[10], 1009 [16]). Here the Court of Justice stated in its judgment:

[The argument that "sex" includes sexual orientation], which does not in any event appear to reflect the interpretation so far generally accepted of the concept of discrimination based on sex which appears in various international instruments concerning the protection of fundamental rights, cannot in any case constitute a basis for the Court to extend the scope of Article 119 of the Treaty. That being so, the scope of that article, as of any provision of Community law, is to be determined only by having regard to its wording and purpose, its place in the scheme of the Treaty and its legal context. It follows from the considerations set out above that Community law as it stands at present does not cover discrimination based on sexual orientation[.] (Grant v South-West Trains [1998]: 1013 [47])

This precedent, which, in any case, is concerned solely with Article 119, concerning equality of pay, of the Treaty Establishing the European Community, is predominantly addressed to a different argument from the one that I am putting forward. The argument that the CJEU here rejects is a linguistic one, that the word "sex" should be construed so as to include sexual orientation (Grant v South-West Trains [1998]: 1013 [43]). My argument is, by contrast, that, on a proper analysis, there is no need at all to invoke the concept of sexual orientation in establishing direct discrimination because of sex. (Compare the example given in his opinion by Advocate General Elmer: "[t]he provision must therefore also be regarded as precluding an employer from, for instance, denying a household allowance to an employee for sons under 18 living at home when such an allowance in otherwise equivalent circumstances was given for daughters living at home" (Grant v South-West Trains [1998]: 999 [16]; cf. also 1000-1001, [21] and [22]). This makes it clear that sexual orientation does not have to be in view.) The court also stated that the allegedly discriminatory travel concessions: 
applied regardless of the sex of the worker concerned. Thus travel concessions are refused to a male worker if he is living with a person of the same sex, just as they are to a female worker if she is living with a person of the same sex. (Grant v South-West Trains [1998: 1001 [27]])

But this is just another example of the "hits both sexes equally hard" fallacy discussed above- the reason why the person is being turned away is because he or she is accompanied by someone of the same sex, rather than someone of the opposite sex. So, the Court of Justice's argument in this paragraph is also unpersuasive.

There are several cases where the Court of Justice has found direct discrimination on grounds of sexual orientation that would have been better judged as examples of direct discrimination on grounds of sex. ${ }^{16}$ One such is the case previously mentioned as cited by Lady Hale as precedent for deciding Bull and Bull v Hall and Preddy [2013], viz. Maruko v Versorgungsanstalt der Deutschen Bühnen [2008]. Here Tadao Maruko complained to the court that he had been denied a widower's pension on the death of his life partner, who had been a member of the German Theatre Pension Institution. The Court of Justice held that:

If the referring court decides that surviving spouses and surviving life partners are in a comparable situation so far as concerns that survivor's benefit, legislation such as that at issue in the main proceedings must, as a consequence, be considered to constitute direct discrimination on grounds of sexual orientation. (Maruko v Versorgungsanstalt der Deutschen Bühnen [2008]: 955 [72])

The answer to the implicit question here had, in fact, already been given by the court three paragraphs earlier:

The referring court considers that, in view of the harmonisation between marriage and life partnership [...] a life partnership, while not identical to marriage, places persons of the same sex in a situation comparable to that of spouses so far as concerns the survivor's benefit at issue in the main proceedings. (Maruko v Versorgungsanstalt der Deutschen Bühnen [2008]: 955 [69])

I suggest that once again this is not so much a case of direct discrimination because of sexual orientation, since the law governing life partnerships made no mention of either sexual orientation or sexual practice (see the Gesetz Über die Eingetragene Lebenspartnerschaft quoted in part in Maruko v Versorgungsanstalt der Deutschen Bühnen [2008]: 945-946, [8]-[11], also on-line at https://www.geset ze-im-internet.de/lpartg/BJNR026610001.html, accessed 7 December 2019), but of direct discrimination because of sex, since it was a requirement of a life partnership that the two parties be of the same sex.

\footnotetext{
16 The EU Directives and Charter use the phrase "on grounds of" rather than the Equality Act 2010's "because of", but there seems to be no difference in meaning. It should also be noted that the phrase is "on grounds of sex", not "on grounds of the individual's sex" (cf. Title VII of the Civil Rights Act 1964 in the United States), or anything similarly restricted (Directive 2006/54/EC (2006: art 2(1)(a)), and the Charter of Fundamental Rights of the European Union (2000: art 21(1))).
} 
Similar comments apply to Römer v Freie und Hansestadt Hamburg [2011]: Jürgen Römer was held to have been the victim of direct discrimination on the ground of sexual orientation when he was denied a request to have his pension increased to recognize his life partner, since he would have been granted such an increase had he been married to someone of the opposite sex, on the assumption that "under national law, that life partner is in a legal and factual situation comparable to that of a married person as regards that pension" (Römer v Freie und Hansestadt Hamburg [2011]: 308 [52]). ${ }^{17}$ Again, direct discrimination on the ground of sex would seem to have been the correct judgment here.

\section{Further Implications}

Would this reasoning hold for other cases? Consider the similar case of Black and Morgan v Wilkinson [2013]. This case was listed for a joint hearing with Bull and Bull v Hall and Preddy [2013] at the Supreme Court, but was withdrawn by the appellant, Susanne Wilkinson, at the last minute. The case was very similar to Bull and Bull v Hall and Preddy [2013], except that Black and Morgan were not in a civil partnership. The fact that Hall and Preddy were in a civil partnership was taken as one of the bases of the finding by Lady Hale and Lords Kerr and Toulson that there was direct discrimination on grounds of sexual orientation (Bull and Bull v Hall and Preddy [2013]: 3759B [68]). Lord Kerr explicitly suggested that, had Hall and Preddy not been in a civil partnership, there would have been only indirect discrimination (Bull and Bull v Hall and Preddy [2013]: 3758B [62]). So, it seems certain that, had Black and Morgan v Wilkinson [2013] been heard at the Supreme Court, the court would have found that Wilkinson only indirectly discriminated against Black and Morgan.

Nevertheless, I want to argue, in the light of the foregoing considerations, that, had Black and Morgan v Wilkinson [2013] been heard under the Equality Act 2010, there would have been a well-founded case that Wilkinson directly discriminated against Black and Morgan because of sex. The reason is that the criterion because of which Wilkinson turned away Black and Morgan was very similar to that of the Bulls: "I have sought to restrict the sharing of the double rooms to heterosexual, preferably married couples" (Black and Morgan v Wilkinson [2013]: 2494E [3]). (Note that, as with the Bulls' criterion, the word "heterosexual" is added, even though at that point same-sex marriages were not legally recognized in England and Wales.) This is the description of what happened when Black and Morgan turned up to occupy the double room that Black had booked by e-mail, without mentioning Morgan (Black and Morgan v Wilkinson [2012]: [3] and [22.6]):

On seeing that they were both men, the defendant said that there was a problem as they had booked a double room. She made it clear that she would not

17 The assumption seems to be fulfilled (Römer v Freie und Hansestadt Hamburg [2011]: 307 [45]). 
accommodate them because she did not like the idea of two men sharing a bed.

(Black and Morgan v Wilkinson [2013]: 2495C [6])

The arguments above, rehearsed in connection with the Bulls, suffice to show that there was no direct discrimination on grounds of sexual orientation: Black and Morgan would not have been allowed to share a double room even if just good friends, unmarried opposite-sex couples of heterosexual orientation were not allowed to share double rooms, and a man of homosexual orientation married to a woman of homosexual orientation would have been welcome to share a double room. It seems to me, though, that there would have been direct discrimination because of sex under the Equality Act 2010. If one looks again at the description of what happened, one can see that Wilkinson did not wait to find out whether Black and Morgan were in a civil partnership. Her reason is clear: "she did not like the idea of two men sharing a bed" [2013]: 2495C [6]. It is absolutely clear that the motivating premiss, the ground, here makes reference to sex ("men"), and not to sexual orientation, civil partnership, or even to marriage. So, under the provisions of the Equality Act 2010, Wilkinson must be adjudged to have directly discriminated against Black and Morgan because of sex.

Here is another case in which the analysis presented of direct discrimination because of sex is clearly more accurate than the analysis of direct discrimination because of sexual orientation. Suppose that B and C are both employed by A, and are both bisexual, but that $\mathrm{B}$ is a man and $\mathrm{C}$ is a woman. Each of them is attracted to a man, D, and this is known to A. A dismisses B on the grounds that he cannot stand the "unnaturalness" of B's being attracted to a man. A doesn't dismiss C, as he regards her attraction to D as "natural". It seems to me that the right thing to say here is not that A has directly discriminated against B because of sexual orientation (since B and C have the same orientation, as "orientation" is defined in section 12(1) of the Equality Act 2010); rather, it is that A has directly discriminated against B because of sex (since each of B and C is attracted to D, but only B gets dismissed, and that because he is a man). The underlying point here is that "being attracted to men" is not a sexual orientation known to the Equality Act 2010, while "being homosexual", "being heterosexual", and "being bisexual" are.

Also, legislation invalidating or forbidding same-sex marriage itself will be a case of direct discrimination because of sex. It has always been the case in England and Wales, and, as far as I know, in every jurisdiction, that someone of homosexual orientation has had the same right to get married as someone of heterosexual orientation, and to marry someone of the same or different orientation-as long, historically, as they were of the opposite sex. So, while a law invalidating same-sex marriage is indirectly discriminatory against those of homosexual orientation, it does not directly discriminate against them because of sexual orientation. It does, however, directly discriminate against same-sex couples because of sex, since the invalidation of same-sex marriage, as the name suggests, features sex as the ground of the less favourable treatment (the invalidation of the attempted union with the person in question, which would have been valid had one of the parties been of the opposite sex). This was the judgment of the Supreme Court of Hawai'i in a 1993 case eventually disposed of by constitutional amendment: 
It is the state's regulation of access to the status of married persons, on the basis of the applicants' sex, that gives rise to the question whether the applicant couples have been denied the equal protection of the laws. (Baehrv Lewin (1993): 564)

It should be clear that the reasoning outlined will also be applicable to many other cases in which there is an allegation of direct discrimination because of sexual orientation-many of these will turn out to be cases of direct discrimination because of sex instead. One might wonder, in fact, in the light of the arguments advanced, whether they will all turn out to be cases of direct discrimination because of sex instead-does my analysis rule out there being any case of direct discrimination because of sexual orientation? No: suppose that a hotel put up a sign saying "no people of bisexual orientation in any rooms"; this refusal would constitute direct discrimination because of sexual orientation. ${ }^{18}$ Would it also constitute direct discrimination because of sex? Suppose that the hotel receives an e-mail from someone saying "I am bisexual, but I have never had a partner-may I, then, stay at your hotel in a single room?", signed simply with "Kim". In refusing Kim, the hotel would not be directly discriminating against Kim because of Kim's being a woman attracted to women (as well as men) or because of Kim's being a man attracted to men (as well as women), because the hotel would not know which was the case. Nor would the hotel be directly discriminating against Kim because of actual associations with any person or persons of the same or the opposite sex, since Kim has never had a partner. Does this mean, then, that we have here a case of direct discrimination because of sexual orientation that is not also a case of direct discrimination because of sex?

It seems to me that this is still a case of direct discrimination because of sex, since the role of sex is crucial in the reasoning that leads to the refusal. Recall the words quoted from Advocate General Maduro above:

The discriminator relies on a suspect classification in order to act in a certain way. The classification is not a mere contingency but serves as an essential premise of his reasoning [...] [R]eliance on those suspect grounds is seen by the Community legal order as an evil which must be eradicated. Therefore, the Directive prohibits the use of those classifications as grounds upon which [...] reasoning may be based. In this way, [...] the prohibition of direct discrimination [...] operates as an exclusionary mechanism [.] (Coleman v Attridge Law [2008]: 785-786 [19])

It is clear that the classification of sex still features in the hotelier's reasoning above: the word "bisexual" means "being attracted to people of either sex", so, on the assumption that the hotelier knows what the word means, ${ }^{19}$ the concept of sex

\footnotetext{
18 Of course, this case is quite different from the real case of the Bulls.

19 Perhaps if someone just randomly picked the word "bisexual" out of the dictionary without understanding it, and decided to discriminate on that basis, we'd have a case of discrimination because of sexual orientation without discrimination because of sex. And perhaps if the discriminator did understand it, but discriminated on a different basis from the meaning of the word, e.g. the discriminator simply discriminated against any people that described themselves by something beginning with the letter "b",
} 
is a crucial element in the hotelier's reasoning, since if it were the case that Kim were attracted to different eye colours, rather than different sexes, there would be no problem in the hotelier's view. The reader might ask: but who is Kim's comparator? The comparator would be someone otherwise like Kim but attracted only to people of one sex. The hotelier would have treated this person better than Kim, so direct discrimination because of sex, the sex of the people to whom Kim is attracted, is made out.

It might be objected that this defines "because of sex" too widely. But consider a parallel example: suppose that an employer said to an employee "you're fired; I overheard you say that you would be happy to be friends with both blacks and whites; I am not prepared to employ someone that would be happy to mix up the races like that". It seems to me clear that sacking someone because they would be happy to be friends with both blacks and whites would be direct discrimination because of race. Compare here the remarks of Lord Simon in Applin v Race Relations Board [1974]:

It is inadmissible to read section 1 (1) as if it read "on the ground of his colour." Not only would this involve reading into the subsection a word which is not there; it would also mean that some conduct which is plainly within the "mischief" would escape-for example, discriminating against a white woman on the ground that she had married a coloured man. It would therefore, in my view, be discrimination if the Watsons had treated local authorities seeking boarding-out facilities for coloured children less favourably than they would treat local authorities who either had no coloured children in care or who proffered none for boarding-out. (289H-290A)

Other cases taking a similar line are Zarczynska v Levy [1979], Showboat Entertainment Centre v Owens [1984], and Weathersfield Ltd (t/a Van \& Truck Rentals) v Sargent [1998]. Each of these cases features an employee losing or leaving their job in protest at being ordered to engage in direct discrimination because of race. In each case the court held that the employee had been directly discriminated against because of race, not the employee's race, but the race of the third parties against whom the employee had been told to discriminate. The courts did not, however, require that there actually exist such third parties that had been discriminated against: the mere giving of the order by the employer was enough, whether or not it was carried out. This establishes that in cases of associational discrimination like this it suffices that there potentially be third parties with the protected characteristic, it is not necessary that there actually be third parties with it in addition to the principal victim of discrimination. In consequence, a bisexual person can be discriminated against because of sex for being potentially attracted to both sexes even if there are no actual persons to whom they are in fact attracted.

I should stress, however, that what has been argued above is that every case of direct discrimination because of sexual orientation is a case of direct discrimination

Footnote 19 (continued)

that would also be a case of discrimination because of sexual orientation without discrimination because of sex. 
because of sex (provided that the discriminator understands the concept with which they are working). It has not been argued that every single case in which someone is treated less favourably and the concept of sex plays a role in the reasoning motivating the less-favourable treatment is a case of direct discrimination because of sex. Suppose, for example, that an employee is sacked because they do not treat the sexes equally. In this case the concept of sex plays a role in the reasoning: if the employer had no concept of sex then they would not be able to sack the employee because they did not treat the sexes equally. And the employee is subjected to treatment less favourable than a comparator that did treat the sexes equally would have received. But the employee would surely not have a case for direct discrimination because of sex under anti-discrimination law: Redfearn v Serco Ltd [2006]. At this point it may be asked quite what role the concept of sex does have to play for a finding of direct discrimination because of sex. A version of this question came before the UK Supreme Court in 2018, but Lady Hale commented "It would be unwise in the context of this particular case to attempt to define the closeness of the association which justifies such a finding" (Lee v Ashers Baking Co. [2018]: 433C [33]). I do not intend to rush in here if the then President of the UK Supreme Court considered it unwise in the context of her case.

\section{Conclusion}

Gorsuch J argued in his judgment in Bostock v Clayton County (2020) that if one discriminated because of sexual orientation one ipso facto discriminated because of sex. It has been argued that this applies to the Equality Act 2010 too (provided one understands the concept of orientation with which one is working): cases of direct discrimination because of sexual orientation are also cases of direct discrimination because of sex. It has been further argued that many cases, such as Bull and Bull v Hall and Preddy [2013], that have been held by the courts to be cases of direct discrimination because of sexual orientation, are not cases of direct discrimination because of sexual orientation, but only cases of direct discrimination because of sex. It may be urged that this does not matter because, on my analysis, direct discrimination is still made out. ${ }^{20}$ Nevertheless, it is both of interest to understand the proper foundations of a charge and also important that those against whom the law finds are not said to have done something that they have not in fact done.

Acknowledgements I am especially grateful to Julian Rivers, and to C'Zar Bernstein, Nuno Ferreira, Marie Fox, Richard Gaskin, Matt Gibson, James Heather, Andrew Koppelman, Anne Morris, Debra Morris, Robert Wintemute, and two anonymous referees for this journal. I am also grateful to the audience at the conference "The Equality Act 2010: five-years on" at which an earlier version of this paper was presented. Of course, none should be thought to be in agreement with what I write.

Funding None.

${ }^{20} \mathrm{I}$ am grateful to an anonymous referee for pushing this point. 


\section{Compliance with ethical standards}

Conflict of interest The author declares that he has no conflict of interest.

Open Access This article is licensed under a Creative Commons Attribution 4.0 International License, which permits use, sharing, adaptation, distribution and reproduction in any medium or format, as long as you give appropriate credit to the original author(s) and the source, provide a link to the Creative Commons licence, and indicate if changes were made. The images or other third party material in this article are included in the article's Creative Commons licence, unless indicated otherwise in a credit line to the material. If material is not included in the article's Creative Commons licence and your intended use is not permitted by statutory regulation or exceeds the permitted use, you will need to obtain permission directly from the copyright holder. To view a copy of this licence, visit http://creativecommons.org/licen ses/by/4.0/.

\section{References}

Finnis, John. 2011. Intention in Direct Discrimination. In Intention and Identity: Collected Essays, vol. II, ed. John Finnis. Oxford: Oxford University Press.

Gardner, John. 1998. On the Ground of Her Sex(uality). Oxford Journal of Legal Studies 18(1): 167-187. Hand, Robert. 2011. Public Law 2011(July): 482-490.

Koppelman, Andrew. 1994. Why Discrimination against Lesbians and Gay Men is Sex Discrimination. New York University Law Review 69(2): 197-287.

Koppelman, Andrew. 1996. Antidiscrimination Law and Social Equality. Yale: Yale University Press.

Koppelman, Andrew. 2001. Defending the Sex Discrimination Argument for Lesbian and Gay Rights: A Reply to Edward Stein. UCLA Law Review 49(2): 519-538.

Koppelman, Andrew. 2002. The Gay Rights Question in Contemporary American Law. Chicago: University of Chicago Press.

Pannick, David. 1983. Homosexuals, Transsexuals, and the Sex Discrimination Act. Public Law 1983: 279-302.

Pannick, David. 1985. Sexual Discrimination Law. Oxford: Oxford University Press.

Trispiotis, Ilias. 2014. "Alternative lifestyles" and Unlawful Discrimination: The Limits of Religious Freedom in Bull v Hall. European Human Rights Law Review 2014(1): 39-48.

Wintemute, Robert. 1997a. Recognising New Kinds of Direct Sex Discrimination: Transsexualism, Sexual Orientation and Dress Codes. Modern Law Review 60(3): 334-359.

Wintemute, Robert. 1997b. Sexual Orientation and Human Rights. Oxford: Oxford University Press.

Wintemute, Robert. 2003. Sex Discrimination in MacDonald and Pearce: Why the Law Lords Chose the Wrong Comparators. King's College Law Journal 14(2): 267-281.

\section{List of Laws}

\section{UK}

Sex Discrimination Act 1975

Race Relations Act 1976

Equality Act 2006

Equality Act (Sexual Orientation) Regulations 2007

Equality Act 2010

Marriage (Same-sex Couples) Act 2013

Abroad

Civil Rights Act 1964 (United States)

Charter of Fundamental Rights of the European Union (2000/C 364/01), 18 December 2000 (EU)

Directive 2006/54/EC of the European Parliament and of the Council of 5 July 2006 (OJ 2006 L 204) (EU) 


\section{List of Cases}

\section{UK}

Bristol County Court. Hall and Preddy v Bull and Bull. [2011] EW Misc 2 (CC), [2011] EqLR 283.

Slough County Court. Black and Morgan v Wilkinson. [2012] EW Misc (CC), Claim No. 0UD02282 (unreported), 18 October 2012, Judgment of Ms Recorder Moulder.

Scotland, Court of Session. Advocate General for Scotland v MacDonald, also sub nom Secretary of State for Defence v MacDonald. [2001] ScotCS 140, 2002 SC 1.

Great Britain, Employment Appeal Tribunal. Zarczynska v Levy. [1979] ICR 184.

Great Britain, Employment Appeal Tribunal. Grieg v Community Industry. [1979] ICR 356.

Great Britain, Employment Appeal Tribunal. Showboat Entertainment Centre v Owens. [1983] UKEAT 29_83_2810, [1984] 1 WLR 384.

Court of Appeal of England and Wales. Race Relations Board v Applin [1973] 1 QB 815.

Court of Appeal of England and Wales. Owen and Briggs v James. [1982] ICR 618.

Court of Appeal of England and Wales. James v Eastleigh Borough Council. [1990] 1 QB 61.

Court of Appeal of England and Wales. Bain v Bowles [1991] IRLR 356.

Court of Appeal of England and Wales. Weathersfield Ltd (t/a Van \& Truck Rentals) v Sargent. [1998] EWCA Civ 193, [1999] ICR 425.

Court of Appeal of England and Wales. Redfearn v Serco Ltd. [2006] EWCA Civ 659, [2006] ICR 1367.

Court of Appeal of England and Wales. Bull and Bull v Hall and Preddy. [2012] EWCA Civ 83, [2012] 1 WLR 2514.

Court of Appeal of England and Wales. Black and Morgan v Wilkinson. [2013] EWCA Civ 820, [2013] 1 WLR 2490.

UK House of Lords. Applin v Race Relations Board. [1974] UKHL 3 [1975] AC 259.

UK House of Lords. R v Birmingham City Council. [1989] UKHL 8, [1989] AC 1155.

UK House of Lords. James v Eastleigh Borough Council. [1990] UKHL 6, [1990] 2 AC 751.

UK House of Lords. Nagarajan v London Regional Transport. [1999] UKHL 36, [2000] 1 AC 501.

UK House of Lords. Chief Constable of the West Yorkshire Police v Khan. [2001] UKHL 48, [2001] 1 WLR 1947.

UK House of Lords. Advocate General v MacDonald, also sub nom MacDonald v Advocate General for Scotland. [2003] UKHL 34, 2003 SC (HL) 35.

UK Supreme Court. R (E) v Governing Body of JFS. [2009] UKSC 15, [2010] 2 AC.

UK Supreme Court. Bull and Bull v Hall and Preddy. [2013] UKSC 73, [2013] 1 WLR.

UK Supreme Court. Lee v Ashers Baking Co. [2018] UKSC 49, [2020] AC 413.

Europe

Court of Justice of the European Communities. Grant v South-West Trains. [1998] EUECJ C-249/96, [1998] 1 CMLR 993. 17 February.

Court of Justice of the European Communities. Maruko v Versorgungsanstalt der Deutschen Bühnen. [2008] EUECJ C-267/06, C:2008:179, [2008] 2 CMLR 32. 1 April.

Court of Justice of the European Communities. Coleman v Attridge Law. [2008] EUECJ C-303/06, C:2008:415, [2008] 3 CMLR 27. 17 July.

European Court of Justice. Römer v Freie und Hansestadt Hamburg. [2011] EUECJ C-147/08, C:2011:286, [2013] 2 CMLR 11. 10 May.

\section{United States}

Supreme Court of Hawai'i. Baehr v Lewin. 74 Haw. 530 (Haw. 1993) 852 P.2d 44.

US Court of Appeals for the Seventh Circuit, Kimberly Hively v Ivy Tech Community College of Indiana. 2017. $853 \mathrm{~F} 3 \mathrm{~d} 339$.

US Supreme Court, Pace v Alabama. 1883. 106 US 583.

US Supreme Court, Plessy v Ferguson. 1896. 163 US 537.

US Supreme Court, Loving v Virginia. 1967. 388 US 1.

US Supreme Court, Phillips v. Martin Marietta. 1971. 400 U.S. 542.

US Supreme Court, Oncale v Sundowner. 1998. 523 U.S. 75.

US Supreme Court, Altitude Express v Zarda. 2020. 590 U.S.

US Supreme Court, Bostock v Clayton County, Georgia. 2020.590 U.S.

US Supreme Court, Harris Funeral Homes v Equal Employment Opportunity Commission. 2020. 590 U.S. 
Publisher's Note Springer Nature remains neutral with regard to jurisdictional claims in published maps and institutional affiliations. 